\title{
Analyzing and Design Supporting System for Knit Fabrics Part 2 : Discrimination of Knit Stitch in Plain Knitted Fabrics Using Template Matching
}

\author{
Mikiya Kondo*, Masayuki Takatera** and Yoshio Shimizu** \\ ${ }^{*}$ Koto Branch, Tokyo Metropolitan Textile Research Institute Honjyo, Sumida-ku, Tokyo, 130-0004, Japan \\ ${ }^{* *}$ Faculty of Textile Science and Technology, Shinshu University, Ueda, Nagano, 386-0018, Japan
}

\begin{abstract}
An non-destructive analyzing system was developed automatically, and the applicability of this system was discussed. The discrimination of the stitch shapes is very important for analysis of the stitch construction of knitted fabrics. To discriminate the stitch shapes, a computer image processing and a pattern recognition were used in the system. The surface image of knitted fabrics was captured with an image scanner. A threshold processing and a histogram processing were used to determine the locations of knit stitches. After detection of stitch regions, the stitch shapes was discriminated using a template matching method. For knitted fabrics in which both back and face loops are used such as links-links and transfer stitches, this system presented in this study can be applied to the analysis of the discrimination of stitch shapes.
\end{abstract}

Key Words : Discrimination of Knit Stitch, Non-destructive Analyzing System,Computer Image Processing, Pattern Recognition, Template Matching

(Received May 17, 1999)

(Accepted for Publication March 10, 2000)

\section{編地分析・設計支援システムの開発}

\section{（第 2 報）テンプレートマッチングによる平編地の編目形状の判別}

\section{近藤 幹也 ${ }^{*}$, 高寺 政行 ${ }^{* *}$, 清水 義雄 ${ }^{* *}$}

\section{1. 緒 言}

編地の設計工程では，新規の編地を設計する上で も，設計デー夕のない既存の編地を再製造する場合 の参考とするためにも, 比較対照とする編地の分析 が必要である。これらの編地の分析は, 熟練作業者 の経験と高度な視覚, 触覚機能に依存しているのが 現状である. 最近では, 精度良く効率的に編地分析
を行える熟練作業者が少なくなってきていることか ら, 編地分析の自動化が強く求められている.

織物に対しては，同様の理由から織物分析の自動 化に関する研究が試みられている1-6)。それらの研 究はたて糸よこ糸という構成要素を持つ織物につい て検討されたものであり, 構成要素がループ状の編 目である編地に対してはまったくなされていない。

編地に対して, 山田ら`は手編記号から編目模様

*会員, 東京都立瀻維工業試験場江東分場, 東京都畦田区本所 3-15- 5, TEL. 03-3624-3731, FAX. 03-3626-5295

**会員, 信州大学紻維学部, 上田市常田 $3-15-1$ 
を生成するシステムを開発し, 伊藤ら ${ }^{8)}$ は, 家庭用 編機および手編みによる編物の編み上がり模様をコ ンピュータディスプレイに表示するシステムを作成 した.さらに, 宮崎ら ${ }^{91}$ は, 同様の手法に基づき, 模式的な手編みの編地画像から手編み記号を生成す るシステムを作成した.

しかし，今日まで，工業用編機で編まれた編地に 対してテンプレートマッチングなどの画像認識手法 を用いて編目形状を自動的に判別する試みは報告さ れていない。

前報10)では, 画像情報解析手法を用いて, 編地上 の編目の位置決め, コースの位置決め, コース数, ウェール数, 編目数の計測を行う方法について考察 を行った。

本報告では，編組織の自動分析技術の開発に資す るため, 前報で用いた編目の位置決めと編目領域の 決定処理を用いて編目領域を抽出し, 抽出した編目 領域に対して、テンプレートマッチングによるパ ターン認識を行うことによって, 編目形状の判別を 試みた。

編地は非常に種類も多く, 生地表面の状態は多岐 にわたるため, 本報告では, 比較的平坦な表目, 裏 目からなるリンクス編および1目の寄せ目の編地を 平編系編地とし，主にこれらの編地で色が黒色以外 の無地のものを実験対象とした．そのため, 表裏で 組織構造の異なるゴム編系組織の編地や立体的な表 面形態をとる縄柄など組織柄の編地に対しては今後 の課題とし，表裏の組織構造に同一性のある平編系 編組織の編目形状の判別を中心に検討を行った。

また，編地の分析においては，すべて表目，す心゙ て裏目といった同一編目で構成されている編地の場 合は，作業者によって容易に判別できるため，複数 の種類の編目が混在している編地の編目種類の判別 と判別した編目の配置を調べる作業が重要となる. そこで，このような異種編目が混在した編地中の編 目の判別を試みた。

\section{2. 画像処理および判別手法}

\section{1 システムの概要}

編地の編目形状を非破壊で分析することを目的と するため, 編地の表面画像をコンピュー夕に入力 し,ソフトウェアにより画像処理および分析処理を 行うものとした.

システムは, 前報10)と同じ島精機スーパーマイク
ロ SDS 原稿固定型 CCD イメージスキャナ，エンジ ニアリング・ワークステーション SUN $4 / 40 \mathrm{EC}$ など の機器から構成される. 画像情報の解析は, エンジ ニアリング・ワークステーションのウィンドウシス テムに画像を表示する解析ソフトを C 言語で制作 した ${ }^{11,12)}$ 。また, デー夕解析の一部には統計解析用 言語パッケージの S 言語13,14)を使用した。

\section{2 編地画像の入力}

編地画像は，編地をイメージスキャナによりス キャンすることで作成した。平編系の編地はカール しやすいため，表面が平坦になる程度に四辺を伸張 してテープで台紙に固定してイメージスキャナの原 稿台に乗せ，外乱光の影響を受けないように原稿台 よりも大きな黒色紙を編地の上に置き，カバーをし て, 内蔵光源による反射光で読み取り，エンジニア リング・ワークステーションの磁気ディスクにラス 夕形式のファイルとして輝度数值で記録し, 以後の 処理に用いる。

\section{3 編地画像の2值化処理と編目領域の抽出}

編地の特徵として, 編地表面にはニードルループ とシンカーループによる編目の穴が存在する。この 穴の部分は画像として背景色になるため，2 值化処 理によりこの穴の部分が閉領域として抽出できれ ば，編目の位置が検出できる．前報10)では，この編 目の穴の位置を検出し，さらに編目の穴部分の閉領 域の大きさを用いて各編目の領域を矩形で設定し, コース位置の検出が可能であることを報告した。

編地画像の 2 值化処理においては, 編地の種類に ようて異なる 2 值化画像が得られる。平編表目の編 地画像を図 1 (a)に, 編目構造の模式図を図 1 (b) に，2 值化画像の例を図 1 (c)に示す. 表目の画像 では, 模式図に示すニードルループとシンカールー プのループの穴部分が規則正しく並んだ 2 值化画像 が得られる。平編裏目の例を図 2 に示す。平編表目 を裏返しただけの平編裏目では，ループの穴の部分 のみが画像として得られるのであれば，表目とほほ 同様の画像となるはずであるが，実際には表目と異 なる画像となる。これは, 裏目では編成時につくら れるループがオールドループに対して裏目側から表 目側に押し込まれていく形となり，図 2 (b) の模式 図に示すオールドループの頂点部分の円弧が常に喠 目側に並ぶため, 2 值化画像においてもオールド ループの頂点部分の円弧が波形に並び図 2 (c) のよ 
うな画像が得られる。

さらに，寄せ目の例を図 3 に示す，寄せ目では， 編目を寄せたことによって生じる空隙部分が大きな 閉領域を構成するとともに，寄せ目周辺の編目が変 形し特徵的な編目形状を有することがわかる.

このように, 編地の画像処理では, 単にループの 穴の形状を反映するのみならず編成系の立体的な位 置関係も反映されるため, 編目の種類により異なる 画像の特徴が得られる．本報告では，このことを利 用して, 編目の穴部分の閉領域周辺の形状から編目 種類の判別を試みた。編目の穴部分の位置決めおよ び編目領域の抽出は，前報(10) と同様に行うものとし た。すなわち，イメージスキャナで読み込んだ画像 上の編目の穴位置の検出を行うために, 編地画像の 輝度分布を調べ，階調ごとの出現頻度をヒストグラ

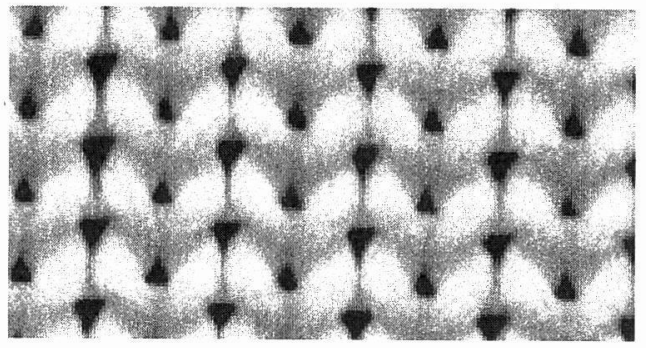

(a) Surface image of front stitch

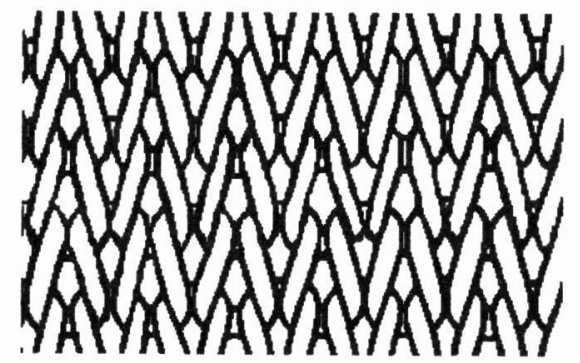

(b) Geometry of front stitch.

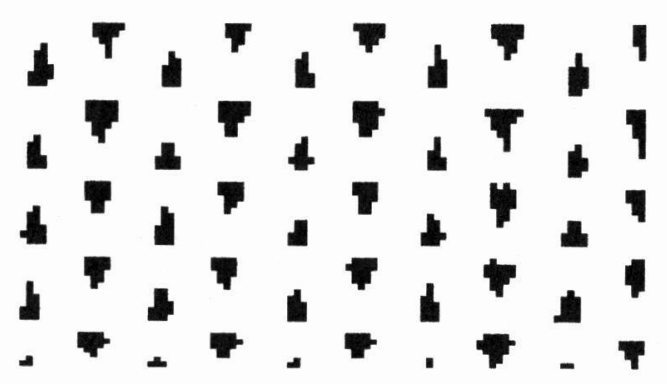

(c) Binary image of front stitch.

Fig. 1 Front stitch.
ム化し, 編地の穴の部分が抽出できるようなしきい 值を操作者が定めて 2 值化処理を行った.

編目画像のヒストグラムは一般にピークが右側に あり，左側に裾を引いた分布形となり，判別分析な どにより手続き的にしきい值を定めるのが困難で あった。そこでしきい值は操作者が以下の手順によ り定めるものとした。

画像の $x$ 方向をコース方向, $y$ 方向をウェール方 向とすると, $x$ 方向, $y$ 方向それぞれ異なるしきい 值 $T_{p x}, T_{p y}$ を用いてそれぞれの方向に走査して得ら れた 2 つの 2 值化画像を作成し，それぞれの方向に 連続する領域が 2 つ 2 值化画像で重なる部分を, 抽出し編目領域とした ${ }^{10)}$.さらに各閉領域を構成す る連続区間の幅のもっとも大きい值を，その閉領域

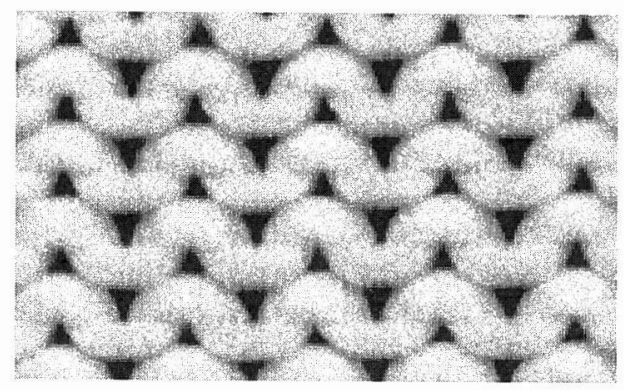

(a) Surface image of back stitch.

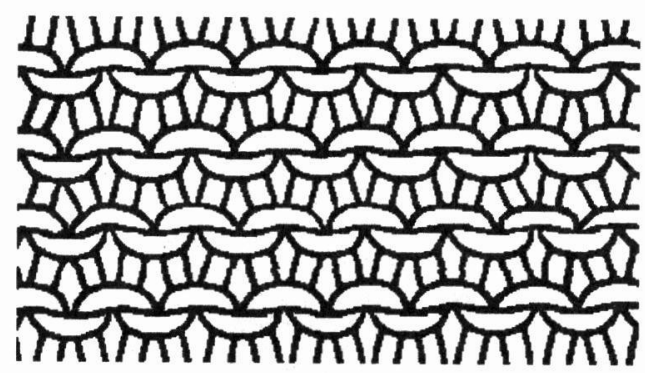

(b) Geometry of back stitch.

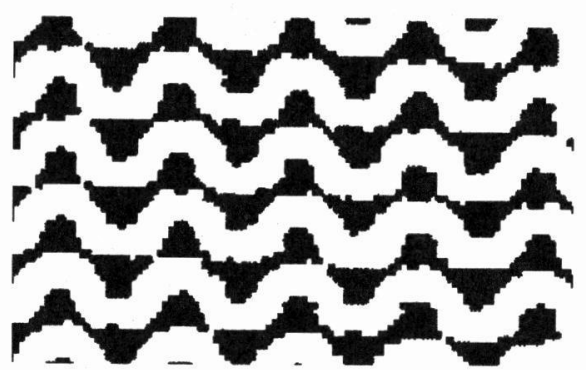

(c) Binary image of back stitch.

Fig. 2 Back stitch. 


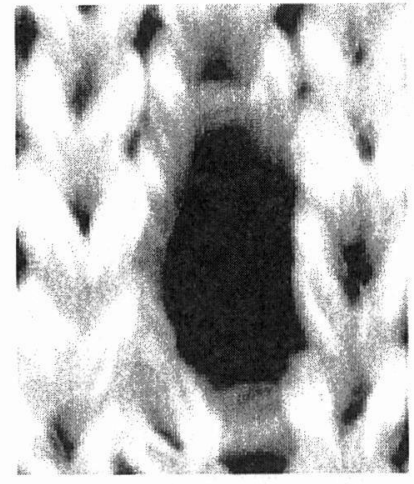

(a) Surface image of transfer stitch.

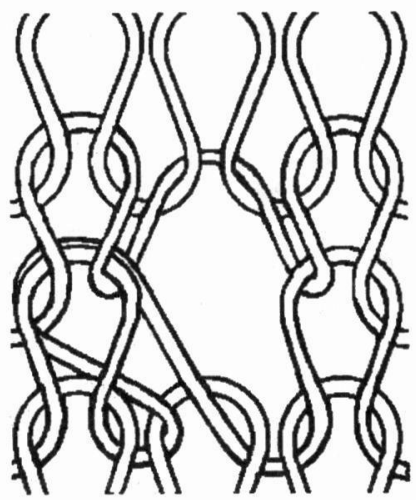

(b) Geometry of transfer stitch.

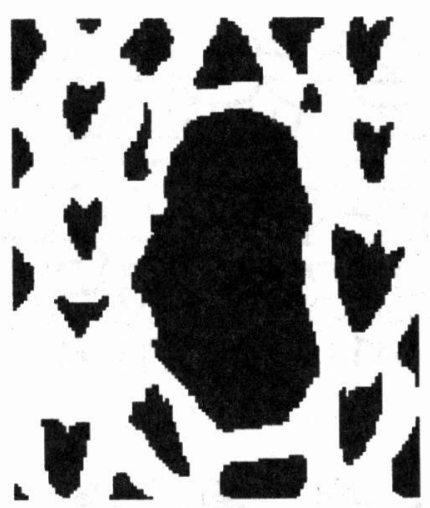

(c) Binary image of transfer stitch.

Fig. 3 Transfer stitch.

の最大幅として $x$ 方向の幅 $w_{x}$ と, $y$ 方向の幅 $w_{y}$ を それぞれ求めメモリに記録する．検出した閉領域の 内部を 2 值化前の画像の輝度で重み付けをして, そ の重心位置座標を求め, 編目領域の位置座標とす る.

各編目領域には, 領域番号を付け, 各重心位置座
標と $x, y$ 各方向の領域幅をメモリ内に記録する. この重心位置座標を中心として, $x$ 方向の幅 $w_{x}, y$ 方向の幅 $w_{y}$ で囲まれた矩形の領域を編目領域とし て取り扱う。

\section{4 テンプレートの作成}

編目領域を構成する閉領域の形状に対して手書き 文字の認識など用いられるテンプレートマッチング 法による画像判別手法を適用して編目形状の判別を 試みた。テンプレートマッチング法はテンプレート と入力画像を照合し, 画像の類似性から画像の種類 を判別する手法である.

照合用テンプレート画像は, 編目種類が既知の編 地をシステムに入力し, 編目領域の抽出を行い得ら れた編目領域画像に対して操作者が編目種類の記号 を定めてテンプレートとした。作成したテンプレー 卜画像の例を図 4 に示す.

\section{5 テンプレートマッチングによる判別処理}

抽出した編目領域とあらかじめ記録しておいたテ ンプレートとの比較は, 画素の輝度階調值の差分 $D$ を求めて行った.

抽出した編目領域を入力画像として, テンプレー トとの重なりの度合いを, 両者の画素の輝度階調値 に差分 $D$ を求めて比較し, 入力画像と最も近いテ ンプレートを決定する処理プログラムを作成した.

なお, 入力画像の画素数は抽出した抽出された編 目領域の大きさとし，この大きさがテンプレートよ りも大きい場合には中心位置であわせて, テンプ レートの大きさで照合を行うこととした，入力画像 の大きさがテンプレートよりも小さい場合のテンプ レートとの照合は, 中心位置であわせて入力画像の 大きさで行った.

$j$ 番目の編目領域の差分 $D_{j}$ は次式により算出し た.

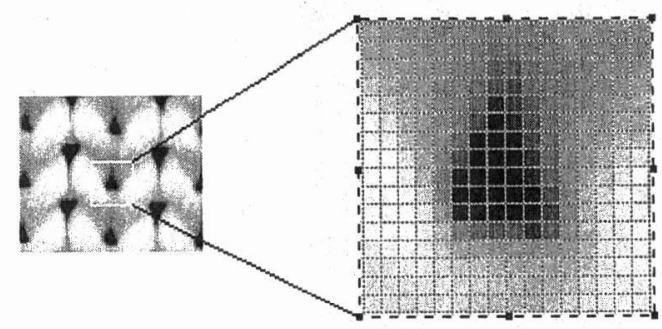

Fig. 4 Example of template image. 


$$
D_{j}=\sum_{i=1}^{n}\left(M_{i}-I_{i}\right)^{2}
$$

ここでnは照合に用いる領域の大きさで, テン プレートと入力画像を比較して小さい方の領域の画 素数である. 縦横16画素の画像の場合は256となる, $i$ は照合に用いる領域内の画素の番号である. $M_{i}$ は テンプレートの輝度階調値, $I_{i}$ は入力画像の輝度階 調值である.

作成したプログラムでは，まず1つのテンプレー 卜 $a$ に対して, 入力画像との差分 $D_{j a}$ を求める.

テンプレートと入力画像の照合を中心位置座標で あわせて行うため, 画像の大きさが偶数画素の場合 などの量子化の誤差を考慮して編目領域の抽出処理 で抽出した編目領域とその位置から $x, y$ 方向に土 1 画素ずつずらして抽出した 8 つ領域を加えて合 計 9 領域をその編目領域の入力画像として扱った.

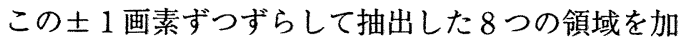
えた合計 9 領域の番号を $k(=1,2,3,4,5,6$, $7,8,9)$ とすると, テンプレート $a$ との差分 $D_{j a k}$ を順に求め, 最も小さい値となった差分 $D_{j a k}$ を $j$ 番 目の編目領域とテンプレート $a$ の差分 $D_{j a}$ とした.

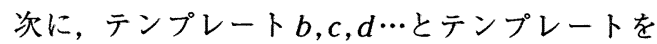
入れ替えてすべてのテンプレートに対して差分 $D_{j}$ を求め, 最も小さい值となるテンプレートを決定す る.

さらに,この一連の処理を, 抽出した全編目領域 に対して行い, 編目形状の判別処理とした.

作成した編目形状判別システムの処理の流れを図 5 に示す。

\section{3. 実験方法}

提案した手法の適用範囲を検討するために実験を 行った. 実験には，当場で編成した編地および編地 サンプル集 ${ }^{15)}$ の編地を用いた。判別実験用編地試料 の概要を表 1 に示す.

編地画像の作成は前報10) と同様に, イメージス キャナでの画像入力時の解像度は $200 \mathrm{dpi}$ で輝度階 調は白黑256階調とし，1024×1024画素で読みこみ, 供試部分を $200 \times 200$ 画素の四角形領域として抜き取 り，処理に用いた。

編組織が既知の各種編地サンプルの編目画像をシ ステムに入力し照合用テンプレートを作成し判別処 理に用いた．編成上は表目，裏目であっても，隣接 編目との関係により編目形状が異なるので, 平編の 表目，裏目に囲まれた表目，パール編中の表目など

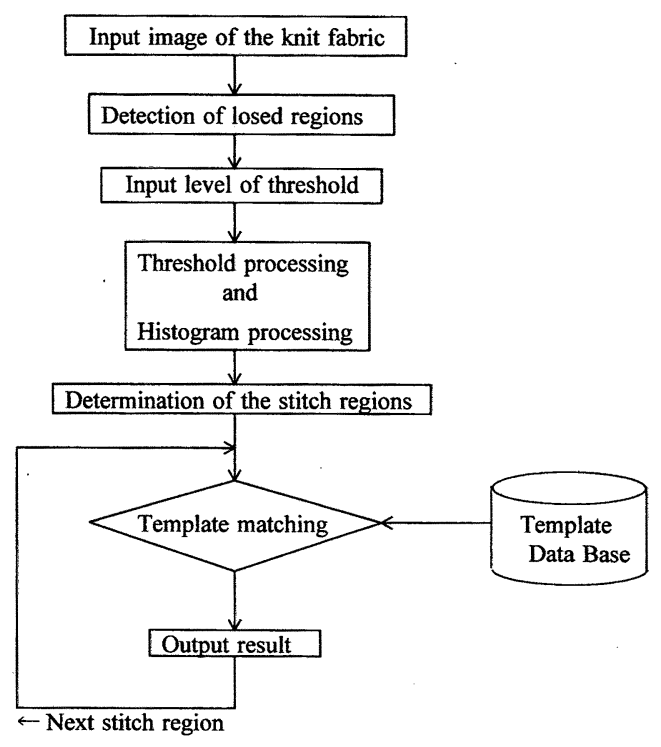

Fig. 5 Flow of the experiment system.

いくつかの特徵的な形状の編目ごとにテンプレート を作成した. 編目種類ごとに作成したテンプレート 数を表 2 に示す.

実験用編地の画像をシステムに入力して判別でき た編目数を記録した.ただし，実験用のサンプルの 素材，色，ゲージ等の条件は，テンプレート作成に 用いた編地に含まれる範囲のものとした，実験用に 用いた編地画像の例を図 6 に示す。

\section{4. 結果および考察}

判別処理の結果を表 3 に示す。一致率は目視によ る編目の判別とシステムによる判別が一致した編目 数が全編目数に占める割合である.

表目の中に裏目が点在するあるいは裏目の中に表 目が点在しているリンクス編の試料 $1,2,3,4$ で は一致率は $95 \%$ \% $98 \%$ と良好であった。裏目の中に 表目が 2 目存在するリンクス編である試料 4 （図 6 (b)）の出力例を図 7 に示す. 全編目数110目中, 目視判別と一致した編目は107目で一致率は97\%で あった。

裏目の中に表目が矩形の領域で存在するリンクス 編の試料 5（図6 (c)）の出力例を図 $8(\mathrm{a})$ に示す. 全編目数 120 目中, 目視判別と一致した編目は87目 で一致率は72\%であった。目視による判別と一致し なかった部分は表目の矩形領域の周辺部に多く, 主 に表目裏目の接する部分の編目であった。

表目の中に裏目の矩形の領域が存在する試料 6 も 
Table. 1 Outline of samples

\begin{tabular}{clllll}
\hline No. & Pattern & Guage & Material & Color & Outline of knit stitches contents \\
\hline 1 & Links & $5 \mathrm{G}$ & wool & white & Back stitch in Front stitches \\
2 & Links & $7 \mathrm{G}$ & wool & white & Back stitch in Front stitches \\
3 & Links & $5 \mathrm{G}$ & wool & white & Front stitch in Back stitches \\
4 & Links & $7 \mathrm{G}$ & wool & white & Front stitch in Back stitches \\
5 & Links & $7 \mathrm{G}$ & wool & white & Front stitch area in Back stitches \\
6 & Links & $7 \mathrm{G}$ & wool & white & Back stitch area in Front stitches \\
7 & Transfer & $5 \mathrm{G}$ & wool & white & Front transfer stitch in Front stitches \\
8 & Transfer $7 \mathrm{G}$ & wool & white & Front transfer stitch in Front stitches \\
9 & Transfer & $5 \mathrm{G}$ & wool & white & Back transfer stitch in Back stitches \\
10 & Transfer & $7 \mathrm{G}$ & wool & white & Back transfer stitch in Back stitches \\
11 & Transfer & $7 \mathrm{G}$ & wool & white & Front transfer stitch in Back stitches \\
12 & Transfer & $7 \mathrm{G}$ & wool & white & Back transfer stitch in Front stitches \\
13 & Mix & $7 \mathrm{G}$ & wool & white & Front Trasfer stitch and Back stitch in Front stitches \\
14 & Mix & $7 \mathrm{G}$ & wool & white & Back Trasfer stitch and Front stitch in Back stitches \\
15 & Purl & $7 \mathrm{G}$ & wool & white & Front stitch and Back stitch \\
16 & 1X1 Rib $7 \mathrm{G}$ & wool & white & Front stitch and Back stitch \\
\hline
\end{tabular}

Table. 2 Outline of templates

\begin{tabular}{clc}
\hline No. & \multicolumn{1}{c}{ Stitch pattern } & Number of templates \\
\hline 1 & Front stitch (Front stitch in Front stitches) & 288 \\
2 & Front stitch (Front stitch in Back stitches) & 208 \\
3 & Back stitch (Back stitch in Back stitches) & 288 \\
4 & Back stitch (Back stitch in Front stitches) & 208 \\
5 & Purl stitch(Front stitch and Back stitches) & 64 \\
6 & Transfer stitch(Front transfer stitctch in Front stitches) & 110 \\
7 & Transfer stitch (Front transfer stitctch in Back stitches) & 36 \\
8 & Transfer stitch(Back transfer stitctch in Front stitches) & 110 \\
9 & Transfer stitch (Back transfer stitctch in Back stitches) & 36 \\
10 & etc & 232 \\
\hline & & Total \\
\hline
\end{tabular}

一致率は $73 \%$ となり，不一致部は試料 5 と同様に表 目, 裏目の境界部分に多く発生していた.

寄せ目では, 図 6 (e).（試料 8 ）のように寄せ目 が点在している試料 7, 8, 9,10,11,12のサンプル では $93 \%$ 96\%と比較的良好な一致率が得られた。 これは, 寄せ目は表目, 裏目の形状よりも編目の穴 が大きく図形的な特徵を有しているためと考えられ る. 寄せ目のある編地で目視による判別との不一致 は, 複数の寄せ目が接近して配置された場合の不規 則に変形した編目に多く見られた。

表目の中に裏目のリンクス編と表目の寄せ目が混 在する試料13（図 6 (f)) について実験を行ったと ころ，84\%の一致率が得られた。ささら裏目の中に 表目のリンクス編と裏目の寄せ目が混在する試料 14
では85\%の一致率であった。これら各種編目が混在 する編地では, リンクス編の矩形領域の周辺部に接 する編目に失敗がみられた。

試料 15 のパール編では $65 \%$, 試料 16 の $1 \times 1$ 針抜 きゴム編は $67 \%$ と, リンクス編，寄せ目より低い一 致率であった。

パール編は図 $6(\mathrm{~g})$ に示すように表目裏目が ウェール方向に交互に連続しているため, すべての 編目が表目裏目の隣接する構造となっている. $1 \times$ 1 針抜きゴム編も図 6 (h)に示すように表目裏目が コース方向に交互に連続しているため, すべての編 目が表目裏目の隣接する構造となっている.

リンクス編の場合も, 表目の中に裹目の矩形の領 域が存在するあるいは裏目の中に表目の矩形領域が 


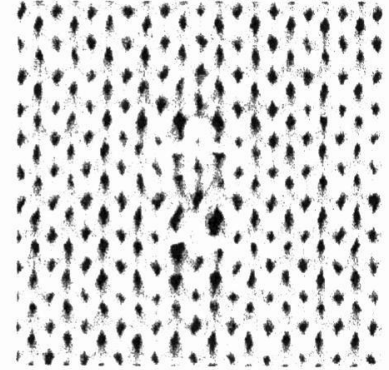

(a) Links (back stitch / front stitch) Sample No.2

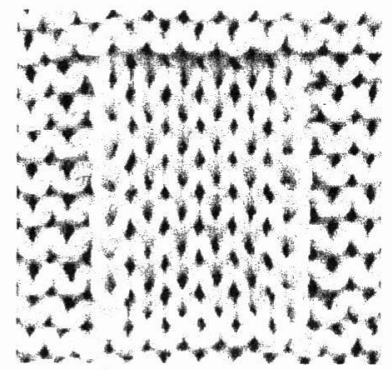

(c) Links (front stitch area / back stitch) Sample No.5

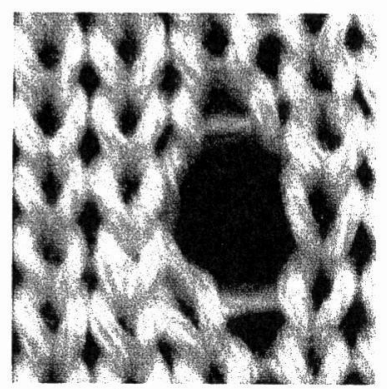

(e) Transfer (front stitch left 1 pitch) Sample No.8

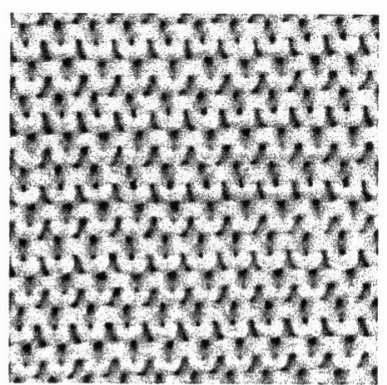

(g) Purl stitch (front and back stitch) Sample No.15

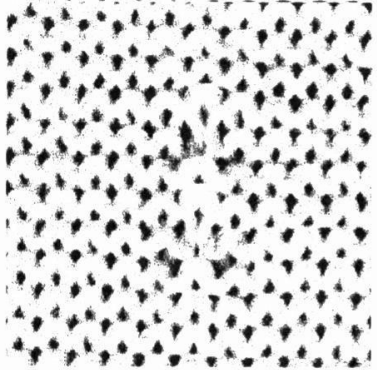

(b) Links (front stitch / back stitch ) Sample No.4

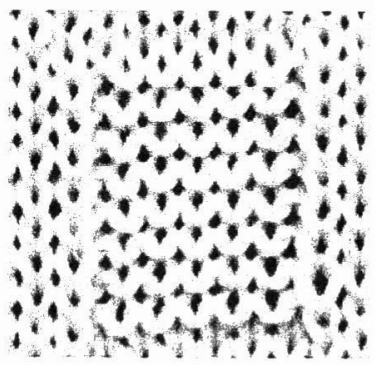

(d) Links (back stitch area / front stitch) Sample No.6

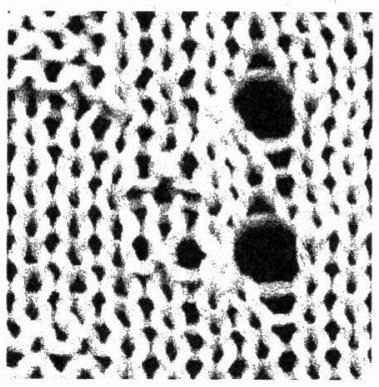

(f) Mixture (links and transfer) Sample No.13

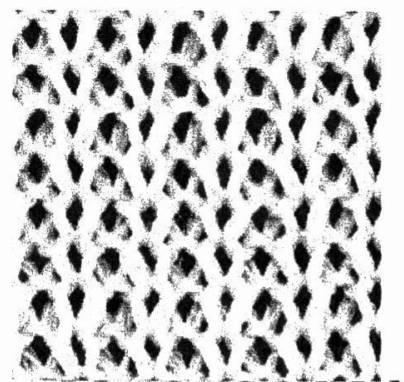

(h) $1 \times 1$ rib stitch Sample No.16

Fig. 6 Examples of experiment knit fabric image. 
Table. 3 Result of discrimination of knit stitch shapes by template matching.

\begin{tabular}{|c|c|c|}
\hline Sample No. & Correct stitch / Whole stitch & Agreement ratio \\
\hline 1 & $71 / 72$ & $98 \%$ \\
\hline 2 & $106 / 111$ & $95 \%$ \\
\hline 3 & $72 / 73$ & $98 \%$ \\
\hline 4 & $107 / 110$ & $97 \%$ \\
\hline 5 & $87 / 120$ & $72 \%$ \\
\hline 6 & $88 / 120$ & $73 \%$ \\
\hline 7 & $68 / 71$ & $95 \%$ \\
\hline 8 & $99 / 104$ & $95 \%$ \\
\hline 9 & $67 / 72$ & $93 \%$ \\
\hline 10 & $101 / 106$ & $95 \%$ \\
\hline 11 & $99 / 105$ & $94 \%$ \\
\hline 12 & $100 / 104$ & $96 \%$ \\
\hline 13 & $88 / 104$ & $84 \%$ \\
\hline 14 & $90 / 105$ & $85 \%$ \\
\hline 15 & $66 / 101$ & $65 \%$ \\
\hline 16 & $62 / 92$ & $67 \%$ \\
\hline
\end{tabular}

*:Whole stitches was determind by hand-operation.

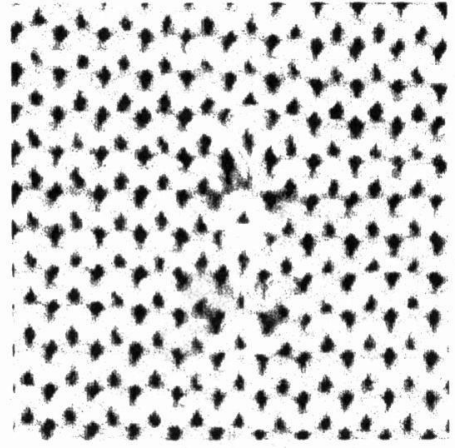

(a) Input Image

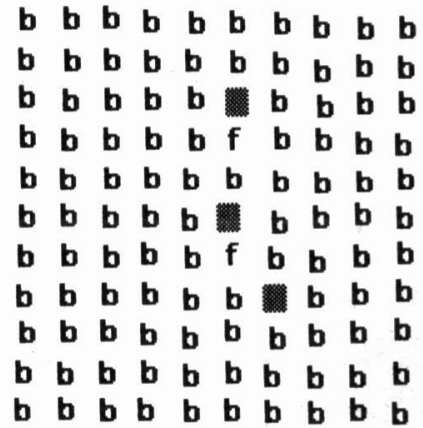

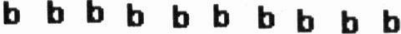

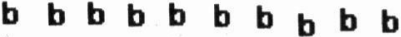

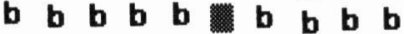

b b b b b f b b b b

b b b b b b b b b b

b b b b b in

b $b$ b $b$ b $f \begin{array}{lllllll} & b & b & b\end{array}$

b b b b b b a b

b b b b b b b b b

b b b b b b b b b b

f : Front stitch

b :Back stitch

:Failure

Fig. 7 Example of output by experiment system for links pattern knit fabric.

存在する試料の判別結果では，表目の中に裏目が点 在するあるいは裏目の中に表目が点在している試料 よりも一致率が低かった。 その際，判別に失敗した 部分はリンクス編の矩形領域の周辺部の表目裏目の 隣接する部分付近に多く発生していた.

編地表側に凸状に出る表目と編地裏側に凹状にへ こむ裏目が隣接する表目と裏目の境界部分では，編 目が立体的になるため，系の太さや然りなどの影響 により編目の穴の形状が不均一となるため判別精度 が低下するものと考える。

そこで，目視による判別と一致しなかった主に表 目と裏目の境界部分の変形の著しい編目について目 視判別の結果をもとに数種の編地からテンプレート を作成し，一致率が75\%以下となった試料番号
$5,6,15,16$ の編地について, 再度判別処理を行っ た. その結果を表 4 に示す.

裏目の中に表目が矩形の領域で存在するリンクス 編の試料 5 (図 6 (c)) の当初の出力例 (図 $8(\mathrm{a})$ ) での一致率は $72 \%$ であったが，テンプレート作成を 行い, 再度判別処理したところ判別可能となった編 目が増加した。 その出力例を図 8 (b)に示す.テン プレートを調整し直して得られた図 8 (b) の出力例 では, 全編目数 120 目中目視判別と一致した編目は 104 目で一致率は $86 \%$ となった. 他の試料について も，表目の中に裏目が矩形の領域で存在するリンク ス編の試料 6（図6(d)）の当初の一致率は72\%で あったが，テンプレートを調整し直したところ，全 編目数120目中目視判別と一致した編目は105目で一 


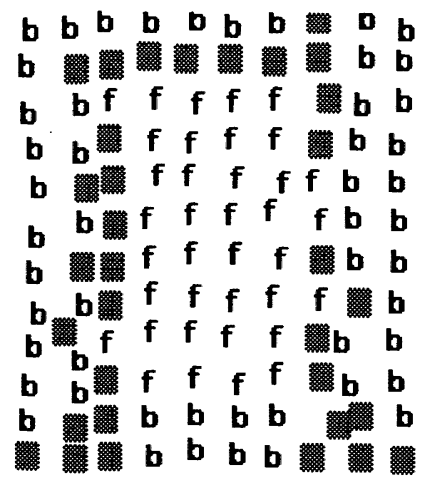

f : Front stitch

b : Back stitch

践 :Failure

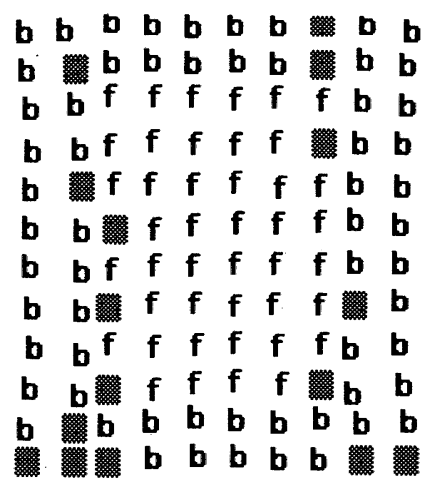

f : Front stitch

b : Back stitch

in : Failure

(b) After tuning template.

(a) 1 st Output.

Fig. 8 Change of output by system after tuning template for Sample No. 5 .

Table. 4 Result of discrimination of knit stitch shapes after tuning template.

\begin{tabular}{|c|c|c|}
\hline Sample No. & Correct stitch / Whole stitch ${ }^{*}$ & Agreement ratio \\
\hline 5 & $104 / 120$ & $86 \%$ \\
\hline 6 & $105 / 120$ & $87 \%$ \\
\hline 15 & $74 / 101$ & $73 \%$ \\
\hline 16 & $72 / 92$ & $78 \%$ \\
\hline
\end{tabular}

致率は $87 \%$ となった．試料番号15のパール編（図 6 (g)）の一致率は $73 \%$, 試料番号 16 の $1 \times 1$ リブ (図 $6(\mathrm{~h}))$ の一致率は $78 \%$ となり，向上が見られた.

以上の結果から，テンプレートマッチングによる 編目形状の判別処理は, 比較的変形の少ない表目, 裏目を持つ編地においては目視判別に近い精度の判 別ができた、しかし, 表目と裏目が切り替わる境界 部分が広い領域にわたる場合, 境界付近の編目につ いては編目の変形が大きく, 変形の少ない編目をテ ンプレートとした判別処理では誤りが多く発生し た.これを改善するために, 境界部分の変形した編 目もテンプレートに含めることにより一致率の向上 がみられた。

このことから, 判別用のテンプレートのデータを 増やし，作業者による簡便なテンプレートの調整機 能などを付加することにより，多種の編目を判別可 能で, より使いやすい実用システムとなるものと考 える。

\section{5. 結 言}

非破壊で編地の編目形状を判別するシステムを開 発し，その有用性を検討した。開発したシステム は, 編地の表面イメージを, コンピュータにイメー ジ・スキャナで読み込み, 得られた編地画像に対し て, 2 值化処理を用いた閉領域の抽出処理を行うこ とによって編目位置の検出と編目領域の抽出を行 い, 抽出した編目領域に対してテンプレートマッチ ングによる画像認識手法を用いて編目形状の判別を 行う.

本システムの出力と目視判別の一致率において は，表目の中に裏目が点在するあるいは裏目の中に 表目が点在するリンクス編で $95 \%$ 98\%, 寄せ編で 93\%〜96\% と比較的良好な結果が得られた。

また，一致率の低かった変形の著しい編目を含む 試料に対しては, テンプレートを再調整することに より, 一致率の向上がみられた。このことから, テ ンプレートの再調整などの操作者の介在を簡便に行 う機構を付加することなどにより，一層実用性の高 
いシステムが実現可能であるとの知見が得られた. 本手法では, 編地の表面画像を用いて解析してい るため，平編系編地を主に実験を行った，裏側の組 織が存在するゴム編系組織に適用するためには，裏 面画像の解析を併用することなどの改良が必要と考 える。また，立体的な編柄のある編地の分析には， 複数の編目の情報を用いて判別するなどより高次の 判別機能が必要となると考える

\section{参考文献}

1）太田健一, 坂上勝彦, 田村秀行 ; 䄉機誌, Vol. 36 , No. 10 (1983)

2）太田健一, 高橋邦彦, 佐伯光哉 ; 繊機誌, Vol. 41; No. 8 (1988)

3）太田健一, 坂上勝彦, 小迫秀夫; 電子情報通信学会論文 誌 D - II Vol. J74 - D - II, No. 11 (1991)

4）太田健一, 坂上勝彦, 小迫秀夫, 高岡 昭; 電子情報通 信学会論文誌 D - II Vol. J74 - D - II, No. 11 (1991)

5) 西松豊典; 緎機誌, Vol. 44, No. 6 (1991)
6) 木下瑞穂, 橋本善忠, 秋山隆一, 内山 生; 繊機誌, 40 , p. 463 (1986)

7）山田雅之, 伊藤裕一郎, 世木博久, 伊藤英則; 情報処理 学会論文誌, Vol. 36 No. 11 (1995)

8）伊藤裕一郎, 山田雅之, 世木博久, 伊藤英則; 情報処理 学会論文誌, Vol. 39 No. 1 (1998)

9）宮崎剛, 山田雅之, 島尻優香, 世木博久, 伊藤英則; 情 報処理学会論文誌，Vol. 36 No. 11 (1995)

10）近藤幹也, 高寺政行, 清水義雄; 繊機誌, 51, No. 10 (1998)

11）安居院 猛, 中嶋 正之, 木見尻 秀子, 「C 言語による 画像処理」, 昭晃堂 (1990)

12）森下 茂, 安積 克之,「XView プログラミング入門」, スペック (1990)

13）渋谷 政昭, 柴田 里程, 「Sによるデー夕解析」, 共立 出版 (1992)

14） R.A. ベッカー, J. M. チェンバース, A. R. ウィルクス 著, 㗪谷 政昭, 柴田 里程 訳, 「S 言語」 I, II, 共 立出版 (1991)

15）伊藤 栄三郎, 「JAKDA ニットブック(1)サンプル帳」, 日 本ニットウェアデザイン協会（1986） 